\title{
The Double Life of Property: Mobilizing Land and Making Capitalism in Modern France
}

DOI:

$10.1086 / 705369$

Document Version

Accepted author manuscript

Link to publication record in Manchester Research Explorer

\section{Citation for published version (APA):}

Yates, A. (2019). The Double Life of Property: Mobilizing Land and Making Capitalism in Modern France. Critical Historical Studies, 6(2), 247-278. https://doi.org/10.1086/705369

\section{Published in:}

Critical Historical Studies

\section{Citing this paper}

Please note that where the full-text provided on Manchester Research Explorer is the Author Accepted Manuscript or Proof version this may differ from the final Published version. If citing, it is advised that you check and use the publisher's definitive version.

\section{General rights}

Copyright and moral rights for the publications made accessible in the Research Explorer are retained by the authors and/or other copyright owners and it is a condition of accessing publications that users recognise and abide by the legal requirements associated with these rights.

\section{Takedown policy}

If you believe that this document breaches copyright please refer to the University of Manchester's Takedown Procedures [http://man.ac.uk/04Y6Bo] or contact uml.scholarlycommunications@manchester.ac.uk providing relevant details, so we can investigate your claim.

\section{OPEN ACCESS}


The Double Life of Property: Mobilizing Land and Making Capitalism in Modern France

Readers of nineteenth century French economic writings will quickly be struck by their preoccupation with the relationship between landed property - with its seemingly natural productivity and durable materiality - and the abstract wealth of the commercialized and financialized economy. This relationship permeates discussions and crosses genres, appearing as both topic and analogy in works of formal political economy, public administration, legal disquisition, and entrepreneurial endeavour. It is at work when a state official during the French Revolution assures readers that his plan for a new currency is based on the ineffaceable security of land, and so "can never suffer a decline in value;" when a prominent banker in 1820 explains that his securities "are a means of fixing property's real value in a representative and circulating sign, granting them all the characteristics and guarantees of its realness;" in a petition to the legislators of the new Second Republic in 1848 that calls for a 'National Real Estate Bank of France' whose notes will be issued on the basis of the nation's "truest value": real property; and when a legislator designing the property code for a French protectorate in 1885 recognizes land as "the true wealth" of the territory and proposes to "turn it into a sort of registered security, circulating as easily as any other." ${ }^{11}$ Widening the lens still further, we find the same terms and

This article has benefited from the support of the School of Arts, Languages, and Cultures at the University of Manchester, a Mellon/Newton Postdoctoral Fellowship at the Centre for Research in the Arts, Social Sciences, and Humanities at the University of Cambridge, and a Prize Fellowship at the Centre for History and Economics, Harvard University. The author would like to thank the editors and anonymous reviewers of Critical Historical Studies for extremely helpful feedback, to express gratitude for the close readings and comments of Rafe Blaufarb, Sarah Roddy, and Michael Pettit, and offer appreciation for the contributions of the participants in the Wake Forest history seminar, the Richard Robinson Business History Workshop, Portland State University (2014), workshops at the University of Cambridge ('New Pathways in Political Economy,' 2015 and 'Urban History: Space, Place, and Connections' at the Centre for History and Economics, 2017), and at the 'Revising the Geography of Modern World Histories' conference at the University of York, 2018.

\footnotetext{
${ }^{1}$ Martin-Philippe Mengin, Nouveau plan d'hypothèque (Paris: Imprimerie des Amis Réunis, n.d. [1790]), 70; Caisse hypothécaire, Statuts (n.p., n.d., [1820]), 5; Anon., Organisation hypothécaire, qui prendrait le nom de Banque Nationale Immobilière de France (Paris: Guillois et Cie, 1848), 3; M. Pontois, "Projet de loi sur la constitution de la
} 
ambitions occurring earlier - as when financier John Law pitched a land bank in 1705, on the premise that land is more durable than precious metals and will always increase in value - and continuing later - in, for instance, land governance and development initiatives of the World Bank today. ${ }^{2}$

The age of modern state formation, imperial expansion, and capitalist acceleration, the nineteenth century was defined by global ideologies of property. ${ }^{3}$ In France, the above formulations formed part of a longstanding and vigorous debate on something known as the "mobilization of land": methods for rendering the circulation of real property (land and buildings) and the values it represented easier and more productive, largely on the basis of improving the security and transparency of property records. ${ }^{4}$ At first glance, complex and arcane matters like mortgage debentures, property registration, and land transfer practices are unlikely candidates for ardent public engagement. Yet, aside from the fundamental economic significance of real property in a country where, for most of the century, half the workforce made its living from agriculture and where land ownership was dispersed amongst millions of smallholders, participants in these discussions recognized that, in the words of legal scholar Robert Ellickson, "the seemingly technical question of whether [we might add "how"] land can be bought or sold lies at the core of social organization." As a particular strain of property

propriété foncière en Tunisie," Revue algérienne, tunisienne et marocaine de législation et de jurisprudence, vol. 1 (1885): 121-145, 124-5.

2 Antoin E. Murphy (trans. and ed.), John Law's 'Essay on a Land Bank' (Dublin: Aeon Pub., 1994), 65; World Bank Development Topics, Land: http://www.worldbank.org/en/topic/land [accessed May 31, 2019]

${ }^{3}$ Paolo Grossi, An Alternative to Private Property. Collective Property in the Juridical Consciousness of the Nineteenth Century, trans. Lydia G. Cochrane (Chicago: University of Chicago Press, 1981 [1977]) and Charles S. Maier, Once Within Borders: Territories of Power, Wealth, and Belonging since 1500 (Cambridge: Harvard University Press, 2016).

${ }^{4}$ Authors employed a range of terms to refine and situate their arguments: mobilization of territory, mobilization of land, mobilization of property, mobilization of mortgages... Frequently, they slipped between their own appellations, confusing land and rights upon it, soil and the credit it could support. This article uses mobilization as shorthand and distinguishes the nature of projects as necessary.

${ }^{5}$ Robert Ellickson, "Property in Land," Yale Law Journal 1092 (1992-1993): 1315-1400, 1375. By the end of the century an estimated eight million - out of approximately forty million - French citizens owned real property. See 
discourse, mobilization isolated and intensified the contentious relations between landed and 'movable' fortunes (industrial, commercial, and financial capital), the great categories of wealth in political economic thought and fiscal administration. ${ }^{6}$ Real property gained additional significance from the era's "economic nationalism" and the perception that it was national bounded and territorial - in a way that commercial capital was not. ${ }^{7}$ For some contemporaries, the development of wealth from real property even offered a uniquely French path to victory over economic rival Great Britain. ${ }^{8}$ Contests among financial interests were staked on the grounds of mobilization. Saint-Simonian thinkers - members of a school of political economy who believed in development by the reciprocal multiplication of credit and productive infrastructure - sought to 'unlock' the wealth of real property as part of a banking revolution that would undermine the traditionalists of the haute banque and the Banque de France, democratizing credit and transforming social relations. ${ }^{9}$ These debates traversed emotional terrain that implicated questions of national character and divergent visions of economic futures

\footnotetext{
Alfred de Foville, Etudes économiques et statistiques sur la propriété foncière: le morcellement (Paris: Guillaumin, 1885). Holdings of less than 20 hectares constituted nearly half of the country's land surface in this period. See Peter McPhee, "The French Revolution, Peasants, and Capitalism," American Historical Review 94 no.5 (December 1989): 1265-1280, p.1267. On property and French political culture, see Rafe Blaufarb, The Great Demarcation: The French Revolution and the Invention of Modern Property (New York: Oxford University Press, 2016); William H. Sewell, Jr. Work and Revolution in France: The Language of Labour from the Old Regime to 1848 (Cambridge: Cambridge University Press, 1980), especially Chapters 5 and 6; Michael Sonenscher, "Property, Community, and Citizenship," in Cambridge History of Eighteenth-century Political Thought eds. Mark Goldie and Robert Wokler (Cambridge: Cambridge University Press, 2006), pp.465-494. On the centrality of property regimes to state construction, see Huri Isamoglu, ed., Constituting Modernity: Private Property in the East and West (London: I. B. Tauris, 2004).

${ }^{6}$ Edgar Allix, "La rivalité entre la propriété foncière et la fortune mobilière sous la Révolution," Revue d'histoire économique et sociale 6 no.3 (1913): 297-348; on real versus personal property in tax policy, see Jean Bouvier, "Sur l'immobilisme du système fiscal français au XIXe siècle," Revue d'histoire économique et sociale 50, no.4 (1972): 482-493.

${ }^{7}$ David Todd, Identité économique de la France: libre-échange et protectionnisme, 1814-1851 (Paris: Grasset, 2008), esp. Part III.

${ }^{8}$ Alphonse Decourdemanche, Déclaration aux notaires, aux conservateurs des hypothèques [...] (Paris: n.p., 1836), p.15. On the 'French path' of economic modernization, see Jeff Horn, The Path Not Taken: French Industrialization in the Age of Revolution, 1750-1830 (Cambridge, MA: MIT Press, 2006).

${ }^{9}$ On real property and banking in Saint-Simonian doctrine and practice, see Georges Weill, L'Ecole SaintSimonienne, son histoire, son influence jusqu'à nos jours (Paris: Alcan, 1896), 12; Gilles Jacoud, Political Economy and Industrialism: Banks in Saint-Simonian Economic Thought (New York: Routledge, 2010) and Jacoud, "Droit de propriété et économie politique dans la pensée Saint-Simonienne,” Revue économique 65 no.2 (2014): 299-315.
} 
as much as it turned on technical questions of surveying, counting, and authenticating; the mortgage code, as one pamphleteer in 1841 suggested, "grants each of us comfort and joy in life, even as it forms the foundation for the wealth and strength of the nation." ${ }^{10}$ Mobilization was simultaneously a means of constituting property in order to achieve a redistribution of social and material resources among different segments of society, and a genre of writing and debate that worked to divine and fix sources of value in a changing economy. In short, it exemplified contestation over capital's capacity to reorder society.

This article analyzes the articulation of the mobilization question by jurists, politicians, pamphleteers, and political economists in early nineteenth-century France and argues for its importance to understanding the imaginative and institutional construction of capitalism in this period. In reconstructing the debate on mobilization, it contends that real property relations should be central to our account of transformations (and continuities) in capitalist modes of production. The crisis of 2008 and the ensuing Great Recession have generated new awareness of the role of real estate capital in the financialization of the global economy. Scholars in urban studies and the sociology of finance have focused attention on the role of real estate as a 'secondary circuit' for capital accumulation. ${ }^{11}$ Drawing on the insights of Marxist geographers Henri Lefebvre and David Harvey, their analyses place the tension between the movable and the immovable - between circulating capital and fixed space, between abstraction and

\footnotetext{
${ }^{10}$ J.-L. Loreau, Du Crédit foncier et des moyens de le fonder (Paris: Hachette, 1841), 8

${ }^{11}$ Kevin Fox Gotham, "The Secondary Circuit of Capital Reconsidered: Globalization and the US Real Estate Sector," American Journal of Sociology 112, no.1 (July 2006): 231-275; Manuel B. Aalbers, "The Financialization of Home and the Mortgage Market Crisis," Competition \& Change 12, no.2 (June 2008): 148-166; Saskia Sassen, "Mortgage Capital and its Particularities: A New Frontier for Global Finance," Journal of International Affairs 62 , no.1 (Fall/Winter 2008): 187-212; Kathe Newman, "Post-industrial Widgets: Capital Flows and the Production of the Urban," International Journal of Urban and Regional Research 332 (June 2009): 314-331; Neil Fligstein and Adam Goldstein, "The Anatomy of the Mortgage Securitization Crisis," in Markets on Trial: The Economic Sociology of the US Financial Crisis, Part A eds. Michael Lounsbury and Paul M. Hirsch (Bingley: Emerald, 2010), pp.29-70. On financialization more broadly, see Greta Krippner, Capitalizing on Crisis: The Political Origins of the Rise of Finance (Cambridge, MA: Harvard University Press, 2011).
} 
materialization - at the core of the production of space and of capital itself. ${ }^{12}$ New historians of capitalism, in contrast, have been comparatively silent on real property's place in the economy; studies of finance, insurance, and the corporation dominate over land and inheritance, circulation and flow over accumulation and fixity. ${ }^{13}$ In a comparative survey of the regulatory framework of modern capitalism, for instance, historian Alessandro Stanziani declines to discuss markets for real property, contending that they can tell us little about changes in how states approach the organization of exchange because their regulation is so thorough and historically consistent. ${ }^{14}$ Such evasions are particularly striking when compared to the importance granted to land and 'primitive accumulation' in studies of the advent of capitalism. ${ }^{15}$ Recent work is nevertheless beginning to correct this imbalance. Legal scholars working on the economic institutions of the early United States have lately offered significant refinements of our understanding of how land became real estate in that country, transformed into an asset core not only to the economic growth of the colonies but to the imperial project of dispossession. ${ }^{16}$ Their insights have been

\footnotetext{
${ }^{12}$ Henri Lefebvre, The Production of Space trans. Donald Nicholson-Smith (Oxford: Blackwell, 1991 [1974]), David Harvey, The Limits to Capital (Oxford: Blackwell, 1982).

${ }^{13}$ For recent surveys, see Kenneth Lipartito, "Reassembling the Economic," The American Historical Review, 121, no.1 (February 2016): 101-139, and on commodity histories, Joshua Specht, "Commodity History and the Nature of Global Connection: Recent Developments," Journal of Global History 14 no.1 (2019): 145-150.

${ }^{14}$ Alessandro Stanziani, Rules of Exchange: French Capitalism in Comparative Perspective, $18^{\text {th }}$ to early $20^{\text {th }}$ Centuries (Cambridge: Cambridge University Press, 2012).

${ }^{15}$ T.H. Aston and C.H.E. Philpin (eds.), The Brenner Debate: Agrarian Class Structure and Economic Development in Pre-Industrial Europe (Cambridge: Cambridge University Press, 1985); Immanuel Wallerstein, The Modern World-System: Capitalist Agriculture and the Origins of the European World-Economy in the Sixteenth Century (New York: Academic Press, 1974). The evolution of property rights and their role in economic development remains fundamental to legal scholars and a vein of economics and economic history concerned with the contribution of institutions to economic growth. See Ellickson, "Property in Land"; Clare Priest, "Creating an American Property Law: Alienability and its Limits in American History," Harvard Law Review 120 no. 2 (December 2006): 385-459; Stuart Banner, How the Indians Lost their Land: Law and Power on the Frontier (Harvard University Press, 2011). On property rights as economic institutions, see Douglass North, Structure and Change in Economic History (Norton: New York, 1981); Elinor Ostrom, Governing the Commons: The Evolution of Institutions for Collective Action (Cambridge: Cambridge University Press, 1990); Sheilagh Ogilvie and A.W. Carus, "Institutions and Economic Growth in Historical Perspective," in Handbook of Economic Growth eds. Philippe Aghion and Steven N. Durlauf, vol. 2A (Amsterdam: Elsevier, 2014), pp.403-513.

${ }^{16}$ See Clare Priest's forthcoming book, Credit Nation: Property Laws and Institutions in Early America (Princeton University Press) and K-Sue Park, "Money, Mortgages, and the Conquest of America," Law \& Social Inquiry 41 no.4 (Fall 2016): 1006-1035.
} 
brought forward to the nineteenth century by Jonathan Levy and especially Elizabeth Blackmar, whose research on the history of real property inheritance shows how agrarian capitalism and patrimonial principles shape modern modes of corporate accumulation in vitally important and previously ill-understood ways. ${ }^{17}$ Moving beyond the United States, Desmond Fitz-Gibbon has comprehensively tracked the assemblage of a market for real property in nineteenth-century England, and Fahad Bishara has placed mortgage debt and its circulation at the core of a modern, Indian Ocean economy. ${ }^{18}$ Thus, historians are beginning to establish a body of work that, taken together, situates real property relations centrally in accounts of the territorialization (the term is used deliberately) of capitalism in distinct historical settings.

In comparison with this historiography, this article pursues an important shift in emphasis, driven by the curiously consistent way that relations between real property and more abstract forms of capital feature in modern economic discourse and practice. Rather than a terminal story of real property commoditization - from land to chattel, from stock to flow - this article uses a particular debate surrounding the relationship of real property and the market to offer a new interpretation of real property's abstraction that accounts for the difficulty,

\footnotetext{
${ }^{17}$ Elizabeth Blackmar, "Of REITs and Rights: Absentee Ownership in the Periphery,” in City, Country, Empire: Landscapes in Environmental History, eds. Jeffry M. Diefendorf and Kurk Dorsey (Pittsburgh: University of Pittsburgh Press, 2005), pp.81-98; Elizabeth Blackmar, "Inheriting Property and Debt: From Family Security to Corporate Accumulation," in Capitalism Takes Command: The Social Transformation of Nineteenth-century America eds. Michael Zakim and Gary J. Kornblith (Chicago: University of Chicago Press, 2013), 93-117; and Jonathan Levy, "The Mortgage Worked the Hardest: The Fate of Landed Independence in Nineteenth-century America," in Capitalism Takes Command, 39-67. On contemporary transformations, see Natalya Vinokurova, "How Mortgage-Backed Securities Became Bonds: The Emergence, Evolution, and Acceptance of Mortgage-Backed Securities in the United States, 1960-1987," Enterprise and Society, 19 no.3 (2018): 610-660. A note must be made of the attention the new history of capitalism has dedicated to the financial significance of enslaved people's status as real and chattel property; see Bonnie Martin "Slavery's Invisible Engine: Mortgaging Human Property," The Journal of Southern History, 76 no.4 (November 2010): 817-866, and Sharon Murphy, "Securing Human Property: Slavery, Life Insurance, and Industrialization in the Upper South," Journal of the Early Republic, 25 no.4 (Winter 2005): 615-652.

${ }^{18}$ Desmond Fitz-Gibbon, Marketable Values: Inventing the Property Market in Modern Britain (Chicago: University of Chicago Press, 2018); Fahad Bishara, A Sea of Debt: Law and Economic Life in the Western Indian Ocean (Cambridge: Cambridge University Press, 2017).
} 
incompleteness, and even undecidability of this process. ${ }^{19}$ Focusing on contentious interventions in the financial functioning of real property of the 1789 and 1848 revolutions, I draw out the repetitious character of mobilization programs and argue that this mimetic quality stemmed from two chief sources: first, the construction of property in the legal imaginary of the nineteenth century and the modes of argumentation in which significant portions of the debate subsequently transpired; second, a persistent misapprehension regarding nature and the material as sources of economic value.

The question of the material is receiving renewed attention from historians of economic life, and was central to mobilization. ${ }^{20}$ In arguing over legal forms and trying out new modes of handling real property as an asset, mobilizers and their opponents attempted to alternately finesse and stymie a perceived shift toward the dematerialization of securities: a shift from a credit regime based on existing, material stocks of wealth toward one based on intangibles and anticipated returns. ${ }^{21}$ A typical anxious analyst of the changing situation in 1829 declared it an "upheaval in the natural order of things" for "credit on land to be considered inferior to personal credit." Land had a real value, the author explained, "founded on solid and productive source of wealth," whereas the personal credit of the commercial realm was merely "abstract, based only on opinion. ${ }^{, 22}$ Yet this worship of the material failed to acknowledge its own invented elements.

\footnotetext{
${ }^{19}$ On undecidability and the land question, see Ananya Roy, "What is Urban about Critical Urban Theory," Urban Geography 37 no.6 (2016): 810-823.

${ }^{20}$ Kate Smith, "Amidst Things: New Histories of Commodities, Capital, and Consumption," The Historical Journal, 61 no.3 (2018): 841-861, and Kenneth Lipartito, "Connecting the Cultural and the Material in Business History," Enterprise and Society, 14 no.4 (2013): 686-704. The influence of science and technology studies literature on this material turn is significant; see Koray Çaliskan and Michel Callon, "Economization, part 1: Shifting Attention from the Economy towards the Processes of Economization," Economy and Society 38, no.3 (2009): 369-398; idem., "Economization, part 2: A Research Programme for the Study of Markets," Economy and Society 39 no.1 (2010): 132.

${ }^{21}$ Nadine Levratto and Alessandro Stanziani (eds.), Le Capitalisme au futur antérieur: Crédit et spéculation en France, fin XVIIIe - début XXe siècles (Brussels: Bruyland, 2011), esp. Introduction.

${ }^{22}$ Louis Gastaldi, Recherches sur le crédit foncier, ce qu'il est, et ce qu'il devrait être (Paris: Delaunay, 1829), 5. On land's standing in political economy, see Keith Tribe, Land, Labour, and Economic Discourse (London: Routledge \& Kegan Paul, 1978), particularly chapter 5. France's Physiocrats, the first individuals to be called
} 
Those with experience of land and property could not help but be aware of its inconsistent qualities, of the fact that a flood could wipe out a field, a fire destroy a building, a cool season decimate a harvest. Indeed, many projects for the mobilization of land included plans to circumvent or surmount these difficulties. Still, the vulnerability and fungibility that inhered in land as physical matter did not prevent it from figuring in these discussions as the ultimate, enduring, concrete source of value. This dynamic is similar to that described by Rebecca Spang in her work on debates on money in the French Revolution. As she points out, theorists committed to metals as a permanent and fixed source of value for paper notes were well aware of gold and silver's physical mutability, of their capacity to assume heterogeneous and unreliable forms. Nevertheless, for ideological ends their works constructed metals as immutable. ${ }^{23}$ Like these monetary theorists, nineteenth-century mobilizers' obsession with the material and the natural as a source of value generated a persistent gap between the 'stuff' and the experience of economic life that partially explains the recurring and repetitive character of their projects.

Despite not engaging forthrightly with their work of invention, mobilizers' projects teach us important things about the imbrication of physical, durable goods and social institutions of the economy. They show us the action of working the 'matter' of real property - land and buildings as concrete, localized, and bounded physical objects, as well as the material practices of inscription constituting legal rights - into shape and salience, and reveal how that matter matters to the nature and persistence of mobilization efforts in the modern era. ${ }^{24}$ Their questions and practices demonstrate that economic entanglements between people and things (in this case, the

economists, enshrined agriculture as the source of all economic value. See, among recent work, Liana Vardi, The Physiocrats and the World of the Enlightenment (Cambridge: Cambridge University Press, 2012); Manuela Albertone, National Identity and the Agrarian Republic: The Transatlantic Commerce of Ideas between America and France (1750-1830) (Ashgate: Burlington, VT, 2014).

${ }^{23}$ Rebecca Spang, Stuff and Money in the Time of the French Revolution (Cambridge, MA: Harvard University Press, 2015), pp.5-6.

${ }^{24}$ Eduardo M. Peñalver, "Land Virtues," Cornell Law Review vol.94 (2008-2009): 821-888, and idem., "Property’s Memories," Fordham Law Review v.80 (2011): 1071-1088. 
obdurate stuff of land) persist well beyond a purported transition to intangible securities and a relative decline in the economic significance of investment in real property. ${ }^{25}$ Focusing on repeated efforts to validate and manipulate what can be called the double life of real property its capacity to exist as a material, productive entity at the same time as it can support circulating signs representing its value - this article examines a historically specific process of abstraction that takes abstraction's other, materiality, seriously, and argues that consistencies in the material nature of real property help explain the reinstantiations that mark its treatment in modern capitalism. ${ }^{26}$ While thus rooted in a close study of a particular time and place, the article analyzes processes that are reproduced and ongoing in numerous contexts, with consequential local variation.

\section{The Double Life of Property and Revolution}

Real property is always located somewhere, and while mobilization is not a uniquely French story, there are crucial insights to be gained from the French perspective. Property in France was born anew in the nineteenth century, enshrined as a natural and imprescriptible right by the Revolution and solidified in rigorously individualist and absolute terms in the country's Civil Code. ${ }^{27}$ Shorn of the layers of privileges that had defined possession in the ancien régime, it became instead "a private matter, free from feudal rights, free from the community's

\footnotetext{
${ }^{25}$ Gilles Postel-Vinay, "Essai sur les usages sociaux d'un bien moyen. Les prêts sur garantie immobilière en France, XVIIIe-XXe siècles," in Le Capitalisme au futur antérieur, pp.267-293.

${ }^{26}$ On the need for concrete histories of abstraction, see William H. Sewell, Jr., "The Temporalities of Capitalism," Socio-economic Review 6 (2008): 517-537.

${ }^{27}$ Property rights in France and other civil code countries were arguably more absolute than in common law countries. Naomi Lamoreaux, "The Mystery of Property Rights: A U.S. Perspective," Journal of Economic History 71, no.2 (June 2011): 275-306; Julian Hoppit, "Compulsion, Compensation, and Property Rights in Britain, 16881833," Past and Present, no.210 (February 2011): 93-128.
} 
intervention, and from collective use-rights. ${ }^{28}$ New inheritance law mandated equitable inheritance of land amongst children, while the sale of nationalized properties and the steady privatization of common lands reinforced both the marketization of real estate and the political and economic significance of smallholding. ${ }^{29}$ The Civil and Commercial Codes of the Napoleonic legal regime followed eighteenth-century juridical and political economic convention by treating immovable goods as fundamentally different, in their physical features and productive capacities, from movables. ${ }^{30}$ Real estate, the quintessential immovable (immobilier in French), remained in the civil realm, while movables (mobilier) and their transactions - like stocks, bonds, jewelry, paintings, furnishings, ships, and businesses - were assigned to commercial jurisdiction. One of the architects of the code observed in 1801, "the distinction between real estate and movable wealth captures the essence of things purely civil and purely commercial." ${ }^{, 31}$ The divided jurisdictions of the code meant that mobilization questions, such as what formalities ought to accompany the circulation of mortgage debt instruments, were articulated explicitly in terms of the degree of commerciality that could (and

\footnotetext{
${ }^{28}$ Jean-Pierre Jessenne and Nadine Vivier, "Northern France, 1750-2000," in Social Relations: Property and Power eds. Bas van Bavel and Richard Hoyle (Turnheut, Belgium: Brepols, 2010), pp.139-169, 139. See also Jean-Laurent Rosenthal, The Fruits of Revolution. Property Rights, Litigation, and French Agriculture, 1700-1860 (Cambridge: Cambridge University Press, 1992); Genviève Koubi (ed.), Propriété et révolution: Actes du colloque de Toulouse, 12-14 octobre 1989 (Paris: CNRS, 1990); Gérard Béaur, L'immobilier et la Révolution. Marché de la pierre et mutations urbaines, 1770-1810 (Paris: Armand Colin, 1994).

${ }^{29}$ Bernard Bodinier, Eric Teyssier, L'Evénement le plus important de la Révolution: la vente des biens nationaux (1789-1867) en France et dans les territoires annexés (Paris: Editions du CTHS, 2000); Louis Bergeron, "National Properties," in Critical Dictionary of the French Revolution, eds. François Furet and Mona Ozouf (Cambridge: Harvard University Press, 1989), pp.511-518. On the material and political legacies of smallholding, see Peter Jones, "The Challenge of Land Reform in Eighteenth- and Nineteenth-century France," Past and Present no.216 (August 2012): 107-142. On inheritance: Suzanne Desan, The Family on Trial in Revolutionary France (Berkeley: University of California Press, 2004); Jens Beckert, "The Longue Durée of Inheritance Law," Archives européens de sociologie 48 no.1 (2007): 79-120; Philippe Steiner, "L'héritage au XIXe siècle en France. Loi, intérêt de sentiment et intérêts économiques," Revue économique 59 (2008): 75-97. On common land and the Revolution: Peter Jones, "The 'Agrarian Law': Schemes for Land Redistribution during the French Revolution," Past \& Present no.133 (November 1991): 96-133, and Nadine Vivier, Propriété collective et identité communale. Les biens communaux en France, 1750-1914 (Paris: Publications de la Sorbonne, 1998).

${ }^{30}$ For an excellent treatment of movables and immovables, see Spang, Stuff and Money, Chapter 1.

${ }^{31}$ Portalis, "Discours préliminaire sur le projet de Code Civil," (1801) in Discours, rapports et travaux inédits sur le Code Civil, par J.-Etienne-Marie Portalis, ed. Vicomte Frédéric Portalis (Paris: Joubert, 1844), pp.1-62, 47.
} 
should) legitimately adhere to the act in question. ${ }^{32}$ Legal reasoning, then, gave particular attention to moments and means by which real property and commerce could align and provided a powerful framework and vocabulary for the mobilization debate.

The Revolution was also important for influential innovations with the financial life of real property. Most famously, the assignat was introduced in 1790 as a government issued, interest-bearing note intended for the purchase of national lands. Anchored by the material reality (and presumed value) of national territory, these notes combined the mobility of currency with the immobility - and stability - of land. The union of fixed and circulating was intended to counter the fears of financial chaos that both lay and educated economic thought associated with a paper currency, fears directly influenced by the experience of financier John Law's "system" in the early eighteenth century. ${ }^{33}$ As is well known, the production of assignats soon became unmoored from the fixed quantity of national land, and the inflation their overproduction engendered reoccurs in the literature of the nineteenth century - and modern-day economic histories - as a traumatic experience shaping French engagement with modern monetary theory and $_{\text {practice. }}{ }^{34}$

Assignats in fact sprang from a period overflowing with schemes, projects, and fantasies of mobilizing land values. From at least the eighteenth century, visions of translating the security and productivity of land into the basis for national banking, credit, and currency systems had

\footnotetext{
${ }^{32}$ R. Défrétière, Essai sur la condition des marchands de biens. Les données actuelles du problème de la commercialité des opérations immobilières (Paris: Les Presses Universitaires de France, 1923). Gabriel-Victor-Jules Demontzey, Etudes sur le développement parallèle de la propriété mobilière et de la propriété immobilière en droit français, Thèse pour le doctorat, Faculté de Droit, Université de Strasbourg (Strasbourg: Imprimerie Huder, 1854).

${ }^{33}$ Manuela Albertone, "Le débat sur le crédit public en France et la naissance des assignats," in La Pensée économique pendant la révolution française, eds. G. Facarello et Philippe Steiner (Grenoble: Presses universitaires de Grenoble, 1990), pp. 405-429; Thomas Luckett, "Imaginary Currency and Real Guillotines: The Intellectual Origins of the Financial Terror in France," Historical Reflections/Réflexions Historiques, 31 no.1 (2005): 117-139.

${ }^{34}$ Rebecca Spang, "The Ghost of Law: Speculating on Money, Memory, and Mississippi in the French Constituent Assembly," Historical Reflections/Réflexions historiques, 31 no.1 (2005): 3-25.
} 
animated both sophisticated and vernacular development schemes. ${ }^{35}$ The double life of real property provided fecund ground for financial experimentation. For instance, revolutionary legislators also considered plans such as those from merchant Jacques-Annibal Ferrières, who had been promoting land banks since the $1770 \mathrm{~s} .{ }^{36}$ He called for the creation of notes backed on land values, a "signe territoriale" that "represents the wealth of land rather than of persons, and it does so both tangibly and virtually. It places in your hand a field, a farm, a building, which cannot slip away, rather than the products of opinion, which can be exaggerated or false." ${ }^{, 3}$ His project did not come to fruition during the revolution itself, but it was an important inspiration for the Directory's Banque Territoriale, an institution granting loans in the form of 'territorial certificates' on real property, shepherded by economic luminaries such as André-Daniel Laffon de Ladébat, a merchant and financier from Bordeaux, and physiocrat Dupont de Nemours. ${ }^{38}$ The Banque Territoriale was short-lived (1799-1803), and one explanation for its failure - a paucity of information that would have allowed it to effectively compete with existing networks of credit operators - opens up the core area of debate on which mobilizers would engage in the nineteenth century. ${ }^{39}$ Mortgage codes introduced in 1795 and 1798 made the registration of sales and other real property transactions mandatory in order for them to be legal between parties. Similar requirements, deemed necessary for a transparent and reliable property

\footnotetext{
${ }^{35}$ Gilles Postel-Vinay, La Terre et l'argent. L'agriculture et le crédit en France du XVIIIe au début du XXe siècle (Paris: Albin Michel, 1998), 12-13.

${ }^{36}$ Jacques-Annibal Ferrières, Plan d'un nouveau genre de banque nationale et territorial, présenté à l'assemblée nationale (Paris: l'Imprimerie de Monsieur, 1789); idem., Plan de la Banque Territoriale inventée par le citoyen Ferrières (Paris: Imprimerie rue Lepelletier, an VII).

${ }^{37}$ Anon., M. B... (Député à l'Assemblée Nationale), Démonstration géométrique de la base sur laquelle reposent les principes de la Banque Territoriale de M. Ferrières, négociant de Lyon [1789], p. 13.

${ }^{38}$ André-Daniel Laffon de Ladebat, Observations sur le crédit territorial (Paris: Imprimerie de la Banque Territoriale, floréal an X [Mai 1802]). On the Banque Territoriale, see Gilles Jacoud, Le Billet de banque en France, 72-90, and Claude Fohlen, "Une expérience de crédit foncier. La Banque Territoriale (An VII - an XI)," in Mélanges offerts à Gérard Jacquemyns (Brussels: Université Libre de Bruxelles, 1968), pp.275-285.

${ }^{39}$ On the paucity of information networks, see Postel-Vinay, La Terre et l'argent, 163-165. The bank was also accused of malfeasance: Jean-Claude Simonne, Coup d'œil sur le crédit en général et sur la Banque Territoriale (Paris: Bailleul et Rondonneau, Germinal an XII [1804]).
} 
regime, were included in draft forms of the Civil Code. Yet for reasons that eluded contemporaries, they were omitted from the final version. ${ }^{40}$ Article 1583 of the Napoleonic Code recognized sales as legal and complete once consenting individuals agreed to the item to be exchanged and its price. Based entirely on the sanctity of private contract, this system required official recording only for certain acts relating to real property (substitutions, donations, and mortgages) and then only in order for the transaction to be legal vis-à-vis third party claims. The general and automatic legal claims that married women and minors retained on the real property of their husbands and guardians did not have to be recorded, nor, if they were, did their amounts have to be specified. A creditor whose loan was secured on a piece of property could thus be surprised by any number of earlier privileges over "their" collateral.

The Code's provisions reflected Napoleon's approach to property as patrimony to be protected from the market rather than an exchangeable asset whose circulation should be encouraged. He personally rejected earlier mortgage provisions because he deemed them "a system of mobilizing land," whereas the state found its advantage "in the stability of property within the same families." 41 The same priorities governed the controversial inclusion of the doctrine of rescision pour lésion d'outre moitié in the Code. ${ }^{42}$ This provision allows a seller of real property to seek damages or an invalidation of a sale if they suffer a prejudice in excess of half its value. It assumes that real property has an objective value independent of the price attributed to it by contracting parties, and that consequently a deviation of price from value

\footnotetext{
40 "Rapport fait au nom de la Commission du Corps législatif chargée d'examiner le projet de loi sur la transcription en matière hypothécaire, par M. de Belleyme, député," in Raymond-Théodore Troplong, Privilèges et hypothèques. Commentaire de la loi du 23 mars 1855 sur la transcription en matière hypothécaire (Paris: Charles Hingray, 1856), xxii-liv, xxvii.

${ }^{41}$ Cited in Anne-Marie Patault, Introduction historique au droit des biens (Paris: Presses Universitaires de France, 1989), 211.

${ }^{42}$ On lésion d'outre moitié, see Arthur Taylor von Mehren, "The French Doctrine of Lésion in the Sale of Immovable Property," Tulane Law Review 49 (1974-5): 321-328, and Judith A. Miller, "Des contrats sous tension: rétablir la propriété après la Terreur," Annales historiques de la Révolution française no.352 (avril-juin 2008): 241262.
} 
sufficient to violate principles of equity can occur. The doctrine applies in the French case only to real property, whose value it construes as both intrinsic and knowable. ${ }^{43}$ While increasingly condemned in the eighteenth century as a violation of the freedom of contract, and banned during portions of the revolutionary period as a disruption of commercial relations, Napoleon reasserted the importance of such laws for protecting both individual and national patrimony. Rescission, he explained, "is a moral law that concerns territory. The way an individual disposes of some diamonds, some paintings, is of little importance; but how he disposes of his landed property is not without importance to society, and society must set the rules and limits of that right of disposal. ${ }^{, 44}$

The legal and administrative regime that emerged at the turn of the nineteenth century for the transmission and exchange of real property was thus complex and sometimes contradictory. As one pro-mobilization treatise opined in 1841 , "the code of real property is an incongruous work pulled between two opposing principles, the ancien régime and the modern [...] Our law of successions is liberal and democratic, our law on mortgages restrictive and aristocratic..." ${ }^{45}$ The abolition of feudalism and the declaration of private property as a natural and universal right may have transformed real estate into a more transparent object of exchange, but its circulation was governed by intricate regulations and could, in principle, encounter significant obstacles.

\section{Revising Property}

\footnotetext{
${ }^{43}$ Léon Lacomme, Des Mineurs de vingt-cinq ans, en droit romain. De la Rescision de la vente pour lésion en droit français, Thèse pour le doctorat, Faculté de droit de Paris (Paris: Imprimerie A. Parent, 1873), 129; Paul Anglès, De la lésion en droit romain et en droit français, Thèse pour le doctorat, Faculté de droit de Lyon (Lyon: Imprimerie Schneider frères, 1878).

${ }^{44}$ Cited in Anglès, De la lésion, 96-7.

${ }^{45}$ Laudoux Alexandre, Précis de l'influence de la mobilisation de la propriété sur la prospérité nationale (Paris: Vigny et Cie., 1841), 21.
} 
It is important to note that conceptual and practical difficulties were not always of the same order. Complaints from jurists and economists about the insecurity of land title in nineteenthcentury France did not impede individuals from buying, selling, donating, exchanging, bequeathing, inheriting, mortgaging, and enjoying their properties with relative ease and a sense of credible commitment to the enforcement of property rights on the part of the state. Studies of lending on real property in the early parts of the nineteenth century, for example, reveal a fairly comprehensive system of credit operating at the local level in both urban and rural settings. ${ }^{46}$ Moreover, the putatively limited reach of the Code's registration requirements was nevertheless sufficient to significantly enhance the availability of information on real property. While registration did not reach all property transactions, many people did opt to fulfill these formalities, making public the information on ownership, borrowing, and lending that had formerly been guarded by notaries, the public officials charged with authentication of various legal acts. ${ }^{47}$ Nationally, the visibility of property at a distance was legislated (and slowly realized) with the establishment of the cadastre, decreed by Napoleon in $1807 .{ }^{48}$ The public availability of this information changed the credit market, particularly in Paris, where the lien registry developed furthest; new parties had access to information on a previously unmatched scale, and competition between lenders expanded. These new parties, such as the Caisse Hypothécaire, a bank founded by Saint-Simonians Olinde Rodrigues and Prosper Enfantin in 1818 with the goal of "granting engagements on real property the same advantages in credit as

\footnotetext{
${ }^{46}$ Postel-Vinay, Terre et argent, 41-7. See also Philip T. Hoffman, Gilles Postel-Vinay, Jean-Laurent Rosenthal, "Entry, Information, and Financial Development: A Century of Competition between French Banks and Notaries," Explorations in Economic History, 55 (2015): 39-57.

${ }^{47}$ Philip T. Hoffman, Gilles Postel-Vinay, and Jean-Laurent Rosenthal, Priceless Markets: The Political Economy of Credit in Paris, 1660-1870 (Chicago: University of Chicago Press, 2001), Chapter 10.

${ }^{48}$ Florence Bourillon, Pierre Clergeot et Nadine Vivier, eds., De l'estime au cadastre en Europe. Les systèmes cadastraux au XIXe et XXe siècles (Paris: Comité pour l'histoire économique et financière de la France, 2008); Florence Bourillon et Nadine Vivier, eds., La Mesure cadastrale. Estimer la valeur du foncier (Rennes: Presses universitaires de Rennes, 2012).
} 
commercial notes," introduced new terms to mortgage contracts themselves. ${ }^{49}$ In place of the hypothèques of the ancien régime, normally repaid in lump sums at the end of the agreement, these lenders introduced annual repayment schemes. This transformed the stock of capital represented by a given immovable into a flow, making it capable of generating annual income for investors. The innovation of annual payments combining capital and interest on mortgage loans was sufficiently novel that the company's 1820 statutes directed readers to the Dictionnaire de l'Académie Française for a definition of the term 'annuity. ${ }^{, 50}$

The difficulties experienced by the prominent players behind these new institutions generated the first substantial wave of public debate on the state of the country's real property regime. In 1826, prominent banker and deputy Casimir Perier, prompted by a speculative real estate boom (and bust) that shook the Caisse Hypothécaire and other financial institutions, offered a 3000-franc prize for diagnoses and solutions to the regime's current ills. The call generated a number of works on the question, from lesser known volumes such as Louis Gastaldi's Recherches sur le crédit foncier (1829) - which Honoré de Balzac reviewed with disappointment, noting that "The failings of the mortgage system have become so obvious that a work becomes vulgar and trivial in restricting itself to simply pointing them out" - to works that would become touchstones in the mobilization debate down to the end of the century, such as $D u$ danger de prêter sur hypothèque (1829) by Saint-Simonian lawyer Alphonse Decourdemanche. ${ }^{51}$ The debate stimulated government interest when a petition from two jurists named Merger and

\footnotetext{
${ }^{49}$ Caisse hypothécaire, Statuts, 1. See also O. Rodrigues et M. Maas, Théorie de la Caisse hypothécaire (Paris: Delaunay, 1820).

${ }^{50}$ Caisse Hypothécaire. Statuts, 4. For earlier mortgage agreements with lump sum repayments, the formula books for notaries provide abundant examples: e.g. Jean-Baptiste-Hippolyte Cardon, Formulaire général ou modèles d'actes rédigés sur chaque article du Code de procédure civile (Paris: Leloir, 1817). The Caisse Hypothécaire entered liquidation in 1846, its difficulties - like those of the Banque Territoriale before it - attributed in no small part to the country's mortgage regime. Alphonse Courtois, Histoire de la Banque de France et des principales institutions françaises de crédit depuis 1716 (Paris: Guillaumin et Cie., 1875), 164-165.

${ }^{51}$ Honoré de Balzac, Le Feuilleton des journaux politiques, mars 1830; reprinted in Euvres complètes (Paris: Michel Lévy Frères, 1872), vol.22, 33.
} 
Mongalvy reached the Chamber in April 1836 and was reported on by deputy Charles Dupin; responses from prominent legal experts such as Raymond-Théodore Troplong contributed to the Minister of Justice, Comte Martin du Nord, convening a national consultation of courts and law schools on the system of registration and credit on real property in $1841 .{ }^{52}$

Synthesizing the wide range of issues and positions that featured in the pamphlets and press dedicated to mobilization questions in the 1830s and 1840s is challenging. While much of the commentary on offer was expert and erudite, circling a common set of treatises, laws, and problematics, many participants in the discussion were initiates, unknown or anonymous, whose broader political perspectives, experiences, and ambitions are impossible to determine. This is particularly true of the later 1840s, when writing on the subject expanded dramatically. Authors did not always make their understanding of key terms clear, nor apply them consistently. When mobilizers proposed instruments based on the value of land, in particular, they drew on a battery of terms, referring variously to mandats, signes, effets, obligations, billets, bons, monnaie, titres, etc. Projects frequently blurred approaching the value of land as an opportunity for investment and credit expansion with deploying that value as a basis for money creation; plans might call for banks that mixed both, for example, or booster hyperbole could conjoin the two, as when selfdescribed 'honorary' stock broker Pierre Petit proposed reforms that would make mortgage debt "superior to all circulating instruments, superior to real currency itself." $" 53$ Confusion was accentuated by critics ready to dismiss all mobilizing projects, however varied, as dangerous schemes for paper money. Yet clear distinctions did exist. Mobilization proposals might be

\footnotetext{
${ }^{52}$ Chambre des députés, séance du 16 avril 1836, in Archives parlementaires de 1787 à 1860 (Paris: Paul Dupont, 1901), $2^{\mathrm{e}}$ série, tome 102, 164-169; Raymond-Théodore Troplong, Des privilèges et hypothèques, ou Commentaire du titre XVIII du livre III du Code civil (Paris: C. Hingray, 1838), préface. Results of the national consultation were published as Documents relatifs au régime hypothécaire et aux réformes qui ont été proposées (Paris: Imprimerie Royale, 1844), 3 vols.

${ }^{53}$ P.M. Petit, Grand-livre de crédit foncier (Paris: Imprimerie et fonderie de Fain, 1838), p.4.
} 
usefully placed into two general camps: those which adhered to a moderate agenda of legal and administrative reform of the mortgage code, with an eye to improving the security of property rights for owners and creditors, and a smaller group advocating a more radical and transformative agenda, proposing measures that would significantly alter the place of real property in the country's economy.

Decourdemanche and other Saint-Simonians were firmly in the latter camp, though his memorable and widely reprinted assertion, that in France, "strictly speaking, there is not a single property owner who can be certain of not being ousted from a property he owns, nor any lender who can be sure of not losing his claim," resonated with even the most moderate contributors to the mobilization question. ${ }^{54}$ Most participants who reflected on the country's property regime, including the majority of the courts and law faculties contributing to the 1841 consultation, agreed that some revisions were necessary to improve the security of real property as a guaranty. In the existing system, sales often went unrecorded, and when a record did exist, ascertaining its validity meant weeks of tedious research following the traces of successive owners - because information was organized by owner, not by land parcel - through tax offices, mortgage bureaus, civil registry offices, and other administrative locales. Without adjustments to the paper life of property - namely, more comprehensive and rational modes of recording, organizing, and making public information on property transactions - fewer individuals than might otherwise do so would invest their capital in real property. (Though for cautious reformers, like the Royal Court of Paris, the trick was to design a mortgage system that secured owners and creditors without simultaneously making it easier and faster to borrow. ${ }^{55}$ ) Possible solutions ranged from major administrative overhauls, such as combining the multiple government bureaus involved in

\footnotetext{
${ }^{54}$ Alphonse Decourdemanche, Du danger de prêter sur hypothèque et d'acquérir des immeubles (Paris: Moreau, $1829,2^{\mathrm{e}}$ édition), 3.

${ }^{55}$ Documents relatifs au régime hypothécaire, vol.1, p.lvi
} 
the recording of property acts into one "central public archive," to relatively minor adjustments to routine, such as a reorganization of the columns formatting data on the sheets of existing registries. ${ }^{56}$ Even such seemingly mundane modifications could have transformative effects on the standing of real property, as some more far-reaching authors well knew. A plan by one J.-L. Loreau, published in 1841, proposed to combine the offices responsible for real property tax and registration in order to achieve a new way of valuing real property, cleanly drawing up a "balance sheet" for each parcel and making it a transparent asset on par with commercial enterprises. $^{57}$ Similarly, a plan by J.-L. Langlois, a deputy from the Eure, that appeared in 1848 sought to combine the civil registry, cadastre, and mortgage registry in a bid to more closely link personal credit to real property. By assembling different ways of knowing about borrowers and their security, and ensuring that "the person of the borrower would weigh significantly in the decision of the creditor," the scheme would in fact create an entirely new asset. ${ }^{58}$

More ambitious programs of reform moved beyond provisions for improving security of title to plans for the circulation of these newly-cemented claims; this was the true remit of mobilization, and here matters grew considerably more complex. Paper avatars of property ownership, mortgages stood in for a transfer of proprietorship, allowing a debtor to remain in possession of the good that formed the security of the debt (the land) while granting the creditor rights to payments and, in the final eventuality, powers of expropriation over the property. Some mobilizers believed it should be possible for such agreements to change hands by means of simple endorsement, from one creditor to another, after the fashion of bills of exchange. This

\footnotetext{
${ }^{56}$ On a central archive, see Louis Gastaldi, Recherches sur le crédit foncier, ce qu'il est, et ce qu'il devrait être (Paris: Delaunay, 1829), 76-83. The Ministry of Finance addressed the question of administrative reform - namely, the possibility of combining, in various permutations, the offices of Direct Taxation, Registrar, Mortgage Administration, and the Cadastre - extensively in the 1841 legal consultation. See Documents relatifs au régime hypothécaire, vol.3, 532-551.

${ }^{57}$ Loreau, Du Crédit foncier, 20.

${ }^{58}$ [Jean-Louis] Langlois, Du crédit privé dans la société moderne et de la réforme des lois qui doivent le constituer (Paris: Joubert, 1848), 102.
} 
move from fixing land as a secure and transparent asset to mobilizing its credit - the wedding of immobilier and mobilier - represented a significant leap in both legal and moral terms. It required legal revisions that would permit mortgages, which were real and civil (as opposed to personal and commercial) legal claims, to be transferred and exchanged according to the simplified rules of commercial trade. ${ }^{59}$ While not strictly prohibited by law, legal opinion as it was voiced in the 1841 consultation maintained the incommensurability of mortgages and other commercial instruments. The Royal Court of Paris, for instance, concluded that "the consequences of a mortgage contract, the rights it grants over property and the reciprocal obligations it imposes on creditor and borrower" made it both illogical and dangerous to encourage the ability of the creditor "to change from one moment to the next, thanks to a simple endorsement." 60 This was not a simple matter of doctrinaire interpretations of the Civil Code. In statements like that of the Royal Court of Limoges, which saw in mobilization "family farms spread out on the gaming table, mixed in with bearer bonds in the corridors of the Stock Exchange," or that of Lyons, which pleaded that, "in a nation and in a century in which everything is changing, everything moving, it is worthwhile to support the only social element whose endurance and stability combats this general mobility," a deeper concern with the political and cultural qualities of real property and its fixity are evident. ${ }^{61}$ The slippage between transferable paper and transferable patrimonies appeared automatic and calamitous.

Revolutionary precedents haunted this debate. References to assignats cropped up throughout the portions of the 1841 consultation concerned with mortgage transferability; so, too, did debate over a little-known mortgage instrument from the Directory called the cédule. (Figure 1) The ambitions for this instrument, introduced in the mortgage code of 1795, and the

\footnotetext{
${ }^{59}$ Documents relatifs au régime hypothécaire, vol.1, 551.

${ }^{60}$ Documents relatifs au régime hypothécaire, vol.1, 567

${ }^{61}$ Documents relatifs au régime hypothécaire, vol.1, 553.
} 
criticisms that led to its suppression after only three years reappeared consistently throughout the mobilization debate in the nineteenth century. The cédule was a negotiable certificate that a property-owner could seek from state mortgage registries on the basis of an official valuation of their property. ${ }^{62}$ They could be deployed like bills of exchange, thus adding "the capacities of the merchant to those of the property owner." ${ }^{\text {,63 }}$ Described as a "mortgage on oneself" (hypothèque sur soi-même), the cédule forged new legal precedents by essentially establishing a mortgage without a designated creditor. Yet it remained intimately linked to particular properties, a feature its creator, a mortgage registry official named Martin-Philippe Mengin, insisted on as a measure of security. With a privilege over a specific parcel of real estate, rather than an undesignated pool of territory, the cédule was meant to be land itself in circulation. Yet this was precisely what its opponents attacked. Contesting the cédule in 1797, conservative deputy André Joseph Jourdan insisted that mortgages and mobilization were fundamentally antithetical: "the first is a system that reinforces obligations, the second one that destroys them; in the first, claims take on the solidity of property, whereas in the second, they take on the quality of movable goods, monetary goods, even of assignats." 64 In the face of such criticisms, the cédule was eliminated when the mortgage code was replaced by the law of 11 brumaire an VII (1 November 1798). ${ }^{65}$

\footnotetext{
${ }^{62}$ The Code Hypothécaire of 9 messidor An III is available in Bulletin des lois de la République française, 1795 no.164, loi no. 963.

${ }^{63}$ Martin-Philippe Mengin, Ce qu'est réellement et politiquement une cédule (Paris: Imprimerie de Du Pont, n.d.), 2. See also Mengin, Plan de finance pour suffire aux dépenses de l'an 4; casser la planche aux assignats et rembourser à volonté ceux actuellement en circulation (Paris: Imprimerie de Dupont, n.d.)

${ }^{64}$ Le Moniteur Universel, no.104, 14 nivôse an V (3 janvier 1797), 415

${ }^{65}$ Code hypothécaire (Paris: Rondonneau, An VII)
} 


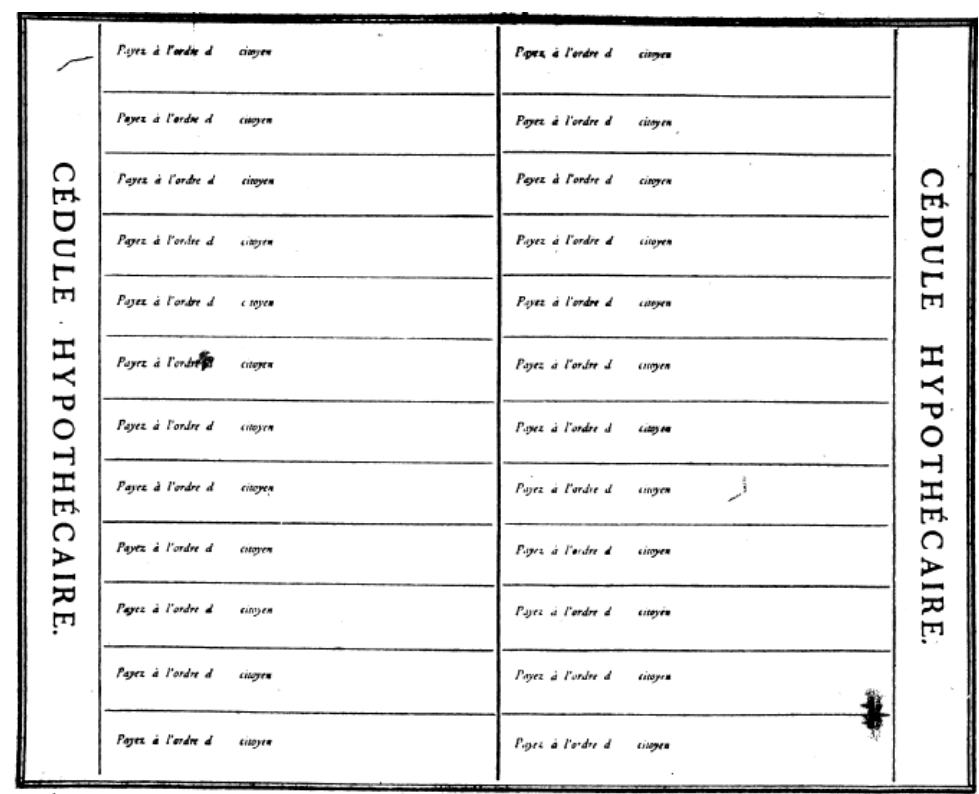

Figure 1: A model of a cédule included in the law of 9 messidor an III. See Bulletin des lois de la République française no.164 (1795). Source: Bibliothèque Nationale de France

Decourdemanche revived interest in the cédule as a model for mobilized real property. He included a model of the 1795 bill in his 1829 work, though he updated the original instrument by proposing a set of intermediary institutions - corporations or business associations - that would enhance the security and appeal of these certificates by guaranteeing the value of the land and ensuring easy repayment to creditors in the event of default. While creditors remained linked to particular properties and able to initiate expropriation proceedings, such direct engagement could be avoided if they preferred. The new cédule could thus be even more liquid than the old, with the result, Decourdemanche wrote, that "the major part of the value of territorial domains will be perpetually circulating., ${ }^{, 66}$ Thanks in part to his authoritative articulation of the project of mobilization, versions of the cédule remained central to the debate until the end of the century, along with the spectre of revolutionary disorder and reform they conjured.

\footnotetext{
${ }^{66}$ Decourdemanche, Du danger de prêter, 43.
} 


\section{The Double Life of Property and Revolution, Again}

The Revolutions of 1848 provided both the political opportunity and the economic incentive to give more thorough consideration to all tenor of mobilizing schemes. 1848 was, amongst other things, a commercial calamity, linked closely to an agricultural crisis. ${ }^{67}$ Diagnoses of the country's financial difficulties in 1848 and 1849 returned often to a lack of cash and the rarity of credit, with some accounts laying the blame on the restrictive policies of the Bank of France. Circumstances led to the imposition of cours forcé and cours légal for the Bank's notes in 1848, meaning that the Bank was not obliged to convert its bills to specie and that they had to be accepted as payment in all transactions. Its issuances were also limited, and its territorial monopoly expanded to encompass the entire country. These changes placed France under the regime of paper money and, for the first time, under one unified monetary system. ${ }^{68}$ Some republicans trumpeted the creation of a homogenous economic space that coincided more closely with national territory. Léon Faucher, a publicist, free-trade economist, and deputy in 1848, considered "a multiplicity of monetary signs as an affliction and a danger for the country," turning it into "something resembling the state of Europe," where each department acts as a sovereign with its own gold and silver currencies. ${ }^{69}$ Still, the new money system aggravated criticisms of the Bank's privileged, monopolistic position, adding accusations that it was hoarding desperately needed specie. ${ }^{70}$

\footnotetext{
${ }^{67}$ Helge Berger and Mark Spoerer, "Economic Crises and the European Revolutions of 1848," The Journal of Economic History 61 no.2 (June 2001): 293-326.

${ }^{68}$ Alain Plessis, "Banque de France," Handbook on the History of European Banking (Aldershot: Edward Elgar Publishing, 1994), 204-209; Gilles Jacoud, “Crises et apprentissage: la Banque de France en 1848," Entreprises et histoire, no.69 (2012): 27-37. Paper money, in the $18^{\text {th }}$ and $19^{\text {th }}$ centuries, referred to notes not exchangeable for specie (gold). See Richard Bonney, "France and the First European Paper Money Experiment," French History 15 no.3 (2001): 254-272; Luckett, "Imaginary Currency and Real Guillotines."

${ }^{69}$ Léon Faucher, "Discussion du projet de loi relatif à la prorogation du privilège de la Banque de Bordeaux (Séance du 21 février 1848), " in Léon Faucher, t. II, Vie parlementaire (Paris: Amyot, 1867), pp.81-108, 86-7.

${ }^{70}$ See, as examples, J.-C. Lambert, Catéchisme du crédit foncier (Paris: Comon, 1849), 30; Pétition à l'Assemblée Nationale pour l'établissement immédiat en France des institutions de crédit foncier (Autun: Imprimeries de
} 
Complaints of hidden capital, available but prevented from circulating, echoed powerfully in projects for real estate banks and land credit that bombarded the country's representatives in the first months of the Second Republic. ${ }^{71}$ The Provisional Government and Constituent Assembly received at least 115 petitions and proposals on the matter in 1848 and 1849. Projects championed land as a uniquely productive asset whose riches were nevertheless trapped in dirt and buildings, or locked as mortgages in portfolios, "dead values" unable to circulate and grow. ${ }^{72}$ Possible methods of achieving that movement were wide-ranging. Some insisted on a state-supervised banking institution, on the model of the Bank of France, which would support real property with loans; others preached free competition and demanded that the private sector - either large corporations or small mutual associations - take charge of evaluating and lending on property. Many projects called for the transformation of land into bills, bonds, or coupons, though whether these should garner interest or not, whether they should circulate by endorsement or remain in deposit, whether they should be convertible into specie or whether they should be established as mandatory legal tender were questions on which participants were deeply divided. (Figure 2)

Dejussieu et Villedey, n.d. [1850]). This was a key vein of criticism among Saint-Simonian polemicists; in 1848, the movement's journal, Le Crédit, founded by Charles Duveyrier, published extensively on parliamentary discussions on mortgage reform and land credit.

${ }^{71}$ Petitions and proposals gathered in Archives Nationales [hereafter AN] C/919/A, while AN F12 6826 contains requests for authorization for mortgage financing institutions from across the country (1849-1850). Dozens more projects were published as studies and treatises during the Second Republic; the Bibliographie de la France lists forty-six substantial publications on the topic for 1848 (Bibliographie de la France (Paris: Pillet aîné, 1848), 277-8). For a summary of the most prominent proposals, see Robert Le Bret, Des procédés de mobilisation de la propriété foncière expérimentés ou proposés en France et dans les principaux états étrangers, Thèse pour le doctorat, Faculté de droit de Paris (Paris: Imprimerie des Ecoles, 1888), 158-212.

${ }^{72}$ On land values as 'valeur morte,' see (e.g.) Gastaldi, Recherches sur le crédit foncier, 28; J. Rambaud, Projet de banque hypothécaire (Lyon: Imprimerie de Boursy, 1848), 2; Jh Denar, Projet d'une banque hypothécaire dont les valeurs circulables ne seraient pas du papier-monnaie mais bien de bons et très bons titres (Lyon: Louis Perrin, 1848), 4. 


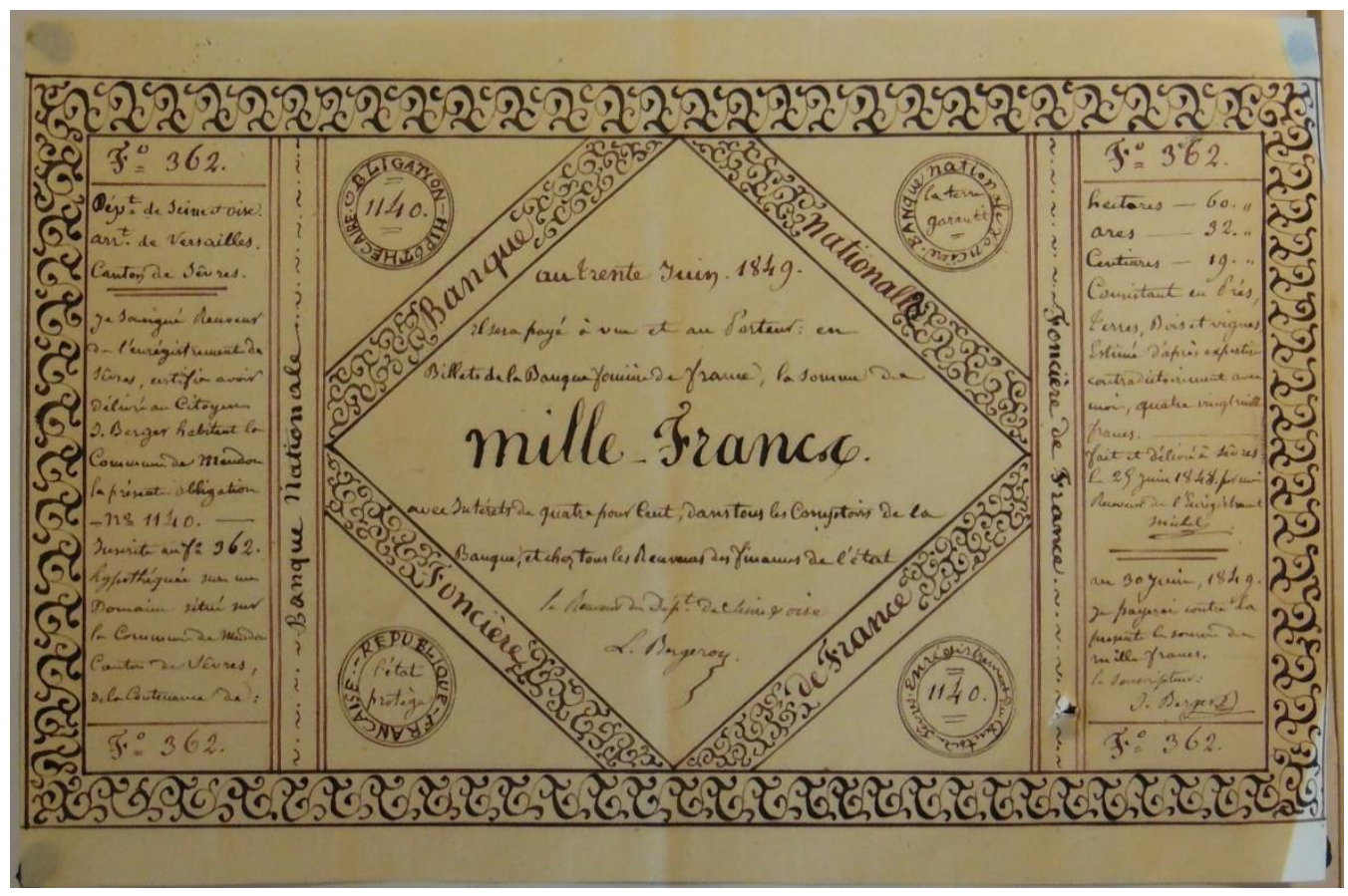

Figure 2: Model for a circulating instrument of the Banque Nationale et Territoriale de France, proposed by one M. Lachapelle, Meudon, Seine-et-Oise, 23 April 1848.

Source: Archives Nationales de France, C/919/A

Reconsideration of real property's financial life was thoroughly imbricated in the debates and upheavals of the Second Republic. Legislators struck three separate committees in 1848 to consider the problem of improving the circulation of capital to and from real property. ${ }^{73}$ Petitions and reports were presented, studied, and debated in quick succession, interrupted and rebooted by revolutionary violence; the June Days postponed the discussion of an important early proposal on mortgage reform, for instance, while one to make debts on real property transmissible by simple endorsement was sidelined by the coup d'état of December 1851. Debate was impassioned, particularly over the question of whether monetary instruments based on the value of the nation's territory could provide a solution to the country's economic woes. Many early proposals explored this option, including that of the Assembly's agricultural committee, which called in October 1848 for the creation of two billion francs of currency guaranteed on

\footnotetext{
${ }^{73}$ For a summary of these committees and resulting proposals, see Jean-Baptiste Josseau, Traité du crédit foncier (Paris: Cosse, 1872), 2 vols., esp. vol 1, 'Historique.'
} 
real property. ${ }^{74}$ The committee invoked (somewhat erroneously) the authority of Jean-Baptiste Say and David Ricardo, as well as sitting Deputy Adolphe Thiers, to produce a defense of paper money, and suggested that "monetized" (monnayée) land need be no more complicated or threatening than any other instrument representing credit, whether the state's or a bank's, particularly given that land was an "acknowledged value, productive in its essence and eminently social." $" 75210$ of the 788 sitting deputies cast their votes in agreement.

Given the unsettling, even infamous precedents of revolutionary monetary experimentation, it is astonishing that this debate transpired at all, let alone drew support from as much as a quarter of legislators. (Figure 3) Key opponents of the proposal were evidently bewildered as well, and drew liberally on memories of assignats and the paper money of financier John Law's eighteenth-century banking scheme in order to deflate any enthusiasm for tinkering with the gap between land's security and its securitization. ${ }^{76}$ These included Louis Wolowski, a jurist, economist, and important contributor on the question of mobilization since the 1830s; Léon Faucher, Wolowski's brother-in-law and fellow member of the Association for Free Trade; and Adolphe Thiers, historian, politician, and future president of the republic. As members of the finance committee studying credit on real property (amongst other matters), they presented a united front against the prospect of turning land into money. Thiers, for instance, was so dismayed by the proposal that he wandered into florid prognostications, reminding legislators

\footnotetext{
${ }^{74}$ For records of the agricultural committee's work, see AN C/927: Registres du Comité de l'Agriculture et du Crédit Foncier (mai 1848 à avril 1849).

${ }^{75}$ Félix Wouters, Histoire parlementaire de l'Assemblée Nationale (Bruxelles: Aux bureaux de l'Association des ouvriers typographes, 1848), vol. 5, 758. See Louis-Hugues Flandin, Rapport fait, au nom du Comité de l'agriculture, sur les propositions des citoyens Turck et Prudhomme, relatives à l'établissement du crédit foncier (Paris: Imprimerie de l'Assemblée nationale, 1849).

${ }^{76}$ Discours prononcé par M. Léon Faucher, représentant de la Marne, dans la discussion des propositions relatives à l'établissement du crédit foncier. Séance du 10 octobre 1848. Extrait du Moniteur Universel du 11 octobre 1848 (n.p., n.d.), 6. This same geneaology appears in Michel Chevalier, La Monnaie (Bruxelles: Meline, Cans et Comp., 1851), 363 .
} 
of "those two terrible memories of the Revolution: the scaffold and paper money," leaving no uncertainty about the dire ends awaiting such modes of mobilization. ${ }^{77}$

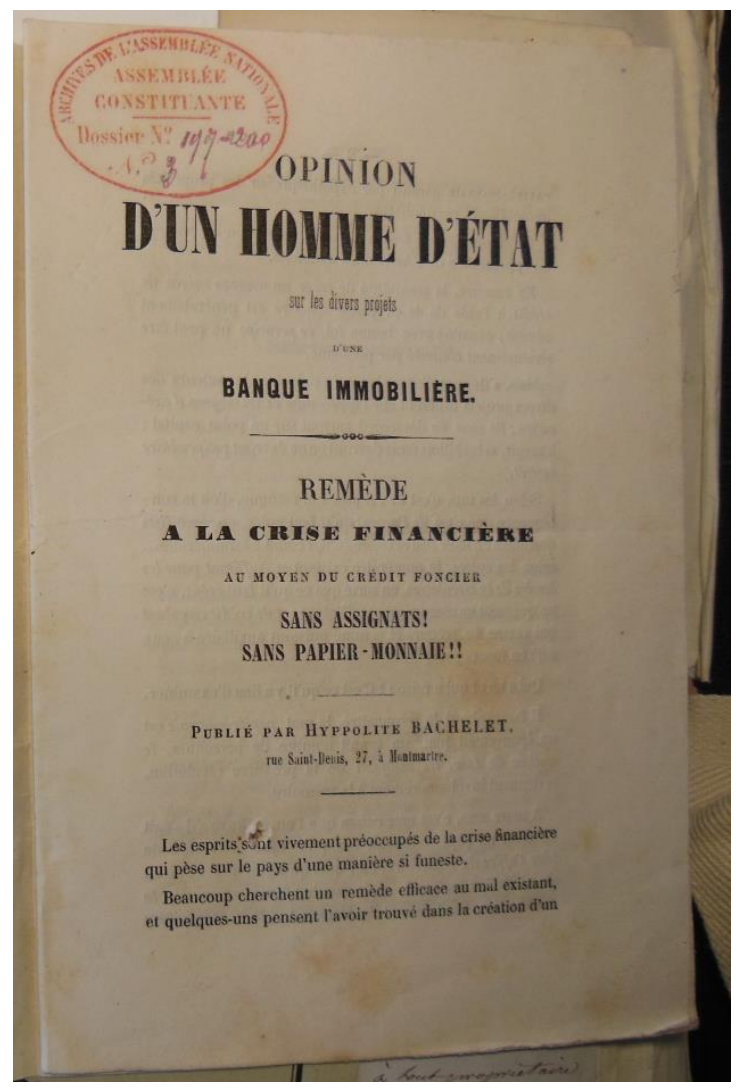

Figure 3: 'Without assignats! Without paper money!!': Cover of a proposal for a Real Estate Bank by Hyppolite Bachelet, 1848. Source: Archives Nationales de France, C/919/A

Yet intervening years of debate had expanded mobilization's range and salience; accordingly, a robust response meant tackling the central contention of mobilization enthusiasts, namely that land and real property were ideal securities. So Faucher contended that in contrast to precious metals, whose value was "definite and universal," the value of property in land was

\footnotetext{
${ }^{77}$ Discours sur le crédit foncier par M. Thiers (Paris: Michel Lévy Frères, 1848), 24, 4. The opposition of Faucher, Thiers, and Minister of Finance Michel Goudchaux is analyzed in Charles Polino, Réfutation des discours des citoyens Goudchaux, Ministre des Finances; Thiers, Léon Faucher, Représentants du peuple, relatifs à l'établissement d'une banque nationale immobilière (n.p.: n.d.), and ibid, Crédit Foncier. Banque Nationale. Nouveau Projet présenté à l'Assemblée législative (Paris: Chez l'auteur, 1850).
} 
"uncertain, variable, local, and arbitrary.",78 Because it was both unpredictable and ungeneralizable, it was a totally inadequate basis for a monetary instrument. Mobilizers, he scoffed, fetishized land and real property, fretting about the best methods of evaluating and communicating its value, all the while forgetting that "land is [only] worth as much as the man who works it is worth." Decrying the agricultural committee's project, Faucher declared to the Assembly that "no matter what you do, credit is always personal; each attempt to make it 'real,' to materialize it, to attach it to a security, is an illusion and a wasted effort." ${ }^{, 79}$ It was impossible to value land in the abstract, separate from the legal institutions, business practices, and local uses by which it was constituted.

The local nature of property markets made certain kinds of arguments about the "illegibility" and thus unreliability of real estate obvious. Mengin, creator of the cédule in the 1790s, formulated a national system of recording and publicizing information on real property specifically to overcome the problem of knowledge at a distance, arguing that "the local knowledge that an owner's neighbours might have on the value and availability of his property is useless to him," given that capital was concentrated in Paris, and of course an owner "cannot bring it to Paris to present it to an investor inclined to grant him a loan." ${ }^{80}$ Léon Michel, a lawyer and frequent writer on property matters, stated the problem simply later in the nineteenth century: "How can you establish a single rate across mortgages, for example, for a field in the Beauce and for a house in Paris?" ${ }^{81}$ Here were commonsense understandings of the problems posed by the inability of property parcels to substitute for one another. Real property's

\footnotetext{
${ }^{78}$ Rapport fait au nom du Comité des finances, sur la proposition du citoyen Pougeard, tendant à remplacer l'impôt extraordinaire de 45 centimes [...] par un emprunt forcé de deux cents millions, payable soit en argent, soit en effets ayant cours de monnaie, par le citoyen Faucher (Léon), représentant du Peuple (n.p., n.d.), 12, 11.

${ }^{79}$ Discours prononcé par M. Léon Faucher, 7-8. On the transition from real to personal credit, see Levratto and Stanziani, eds., Le Capitalisme au futur antérieur.

${ }^{80}$ Martin-Philippe Mengin, Prospectus d'une caisse hypothécaire (n.p., n.d. [1795]), 1-2.

${ }^{81}$ Cited in M. J. Chérest, De la mobilisation du crédit hypothécaire au moyen de titres négociables (Cédule et lettre de rente), Thèse pour le doctorat, Université de Paris Faculté de Droit (Paris: Arthur Rousseau, 1912), 45.
} 
immobility operated in several modes, however. Dismissing "this grand idea, mobilization" in 1848 , Thiers pointed out that "it is impossible to make it so that a mortgage lien has the mobility of a 45-day commercial note in a bank's portfolio." ${ }^{~} 22$ As he understood it, the inability of mortgage debt to act like commercial debt had less to do with land's fixity in space and more to do with its fixity - its slowness - in time. Property's timeline was different from that of other assets. Its capital requirements were long-term requirements, its returns were long-term returns; these conditions resulted from both its nature and its location within an ecology of investment. The great virtue of property was its durability, a feature that arose "from the nature of things" and which ensured that increased mobility, in the unlikely event that it was possible, would add little to its value as an investment. ${ }^{83}$

Proponents of mobilization grappled mightily with this issue of real property's differential relationship to market time. It was potentially a benefit to be exploited. In his 1843 project for the establishment of a state program for mortgage lending, jurist and future deputy Firmin Pougeard reminded his audience that the long-term nature of property investment supplied his program with stability: "It will be remembered, of course, that as we are dealing with mortgage investments, any variation and movement in operations will of necessity be extremely slow, and will thus avoid any unforeseeable or unpredictable developments." ${ }^{\prime 44}$ Similarly, Decourdemanche pushed land's entry into finance as a way of bringing stability to an economy that otherwise risked constant crisis because of the dominance of fluctuating and unreliable commercial sectors. ${ }^{85}$ Yet the gap between speed of capital circulation in the realms of immobilier and mobilier also posed problems. For instance, property values were liable to

\footnotetext{
${ }^{82}$ Discours sur le crédit foncier par M. Thiers, 15

${ }^{83}$ Discours sur le crédit foncier par M. Thiers, 14-15, 20-21.

${ }^{84} \mathrm{~F}$. Pougeard, Du régime hypothécaire considéré comme institution politique et sociale (Bordeaux: Imprimerie de Lavigne, 1843), 20.

${ }^{85}$ Decourdemanche, Déclaration aux notaires, 14.
} 
change over the lifespan of the paper instruments based upon them. When an individual named Nigay presented his proposals to "not simply mobilize, but monetize property" in 1848 , he attempted to compensate for risks of devaluation by developing a scheme that classified "buildings subject to degradation" separately and requiring fire insurance for built properties. ${ }^{86} \mathrm{~A}$ project by R.F. Fresnel in the same year observed that "as long as mobilization is in place, the mobilized properties cannot be allowed to suffer any reduction in their value that would endanger the security of the mobilization:" wood-cutting could not advance abnormally, alterations to built properties would require the authorization of lending authorities, and local mayors would be empowered to monitor all properties, "mobilized or otherwise," for potentially detrimental transformations. ${ }^{87}$ Mobilization projects also frequently recognized and accommodated distinctions between the durable nature of land and the more vulnerable, variable status of constructions by allowing for the former to borrow or generate notes based on a higher proportion of its value. Representative Antoine Galy-Cazalat's 1848 proposal to create two billion francs in mortgage certificates would have allowed owners of rural land to obtain exchangeable notes representing as much as a third of their property's value, compared to only a fifth for built properties; a project signed by the 'Widow Chapet' in the same year would have placed no expiry or final repayment date on notes based on land, while those springing from built properties, "subject to significant depreciation, as well as increases in value," ought to circulate for only five or ten years. ${ }^{88}$

\footnotetext{
${ }^{86}$ Nigay, Principales bases d'un système de crédit foncier, au comité général de l'agriculture et du Crédit Foncier (Paris: Lacour, 1848), 17.

${ }^{87}$ R.F. Fresnel, Mobilisation des propriétés immobilières. Cinq milliards de capital mis en circulation (Paris: Imprimerie de E. Brière, 1848), 14-15.

${ }^{88}$ AN C/919/A: Proposition de M. Galy-Cazalat, Etablissement du crédit foncier sans cours forcé, 1848 ; Lettre de Veuve Chapet à Citoyen Garnier-Pagès, 17 avril 1848.
} 
The question of aligning value on paper and value in buildings and soil makes particularly clear the imperatives that capitalism exerts over time as well as space. Creating the conditions necessary to direct capital towards land - turning it into a secure investment in which capital could enter and exit at will - required managing and transforming the timeframes in which real property operated. Louis Wolowski spoke directly to this imperative in the proposal he submitted to the Assembly in early $1848{ }^{89}$ The Polish expatriate had made forays into the mobilization debate soon after arriving in France in 1831, notably working to popularize Polish and Prussian land credit models. Like Thiers, Wolowski saw land as something that slowed down and extended the time between investment and return. Capital invested in land was sunk, embedded, and recoverable only over long periods of time - indeed, he wrote, "capital expended on improving or acquiring a piece of land ceases to exist as capital and will not return in that form to those who spent it." But does it have to follow, he asked, that "land credit is doomed to be denied speedy transactions and easy collections? Does it have to remain, like the land itself, a heavy and unwieldy machine?" 90 If the problems of land credit came from the nature of land, as so many contemporaries argued, so, too, could their solution. What was required was "an ingenious combination" to "change the form and nature of the investment." 91 In place of the "dead idea" of "mortgage money" Wolowski pursued the "living idea" of "territorial credit.",92 New financial instruments should be created, yes, but these should mirror the nature of land itself: print bonds rather than currency. As he explained in 1848, "if we are to mobilize property,

\footnotetext{
${ }^{89}$ AN C/919/A: Organisation du Crédit Territorial. Texte de la proposition de M. Wolowski.

${ }^{90}$ Ibid.

91 Ibid.

${ }^{92}$ Wolowski, De l'organisation du crédit foncier, 6
} 
its essence must be captured in its representative sign; the paper that it generates must produce interest, just as land produces revenue." 93

This was precisely the option pursued by the government with the law of 28 February 1852, which authorized the formation of companies charged with the issuance of mortgage loans funded on the basis of bonds. Among the first was Wolowski's Banque Foncière de Paris, which evolved into the Crédit Foncier de France (1854) and achieved, for a time, a monopoly on longterm amortizable mortgage loans underwritten by bonds. ${ }^{94}$ The company represented a particular innovation in the abstraction of land. In the process of channeling capital from lenders in search of an investment to borrowers in search of a loan, it created a new type of instrument, commonly referred to at its outset as a "lettre de gage," or mortgage bond. The total value of these bonds could not exceed the total value of loans issued by the company, and the capital of one was guaranteed on the security of the other. Yet the particularization inherent to the mortgage, and so critical to opponents of mobilization, was gone. Bondholders had no claim on a specific parcel of land; rather, their claims were lodged on the mass of mortgage debt consolidated by the company. Jean-Baptiste Josseau, a lawyer and future deputy assigned to several commissions on land credit by the state, explained: "this mortgage instrument detaches the security from the claim. It makes the security a distinct and movable value, which becomes itself the guarantee of the bond issued by the company and taken up by capitalists." 95 Land parcels and personal claims were flattened; Wolowski had explained the necessity of this transition:

For mortgage instruments to circulate like state bonds, for them to have a public rate, their guarantees have to be standardized, they have to be made identical,

\footnotetext{
${ }^{93}$ Wolowski, De l'organisation du crédit foncier, 22

${ }^{94}$ On the Crédit Foncier, see Jean-Pierre Allinne, Banquiers et bâtisseurs - un siècle de Crédit Foncier, $1852-1940$ (Paris: Éditions du CNRS, 1984); Aline Raimbault and Henri Heugas-Darraspen, eds. Crédit Foncier de France. Itinéraire d'une institution (Paris: Editions du Regard, 1994).

${ }^{95}$ Cited by Joseph Josseau, Des Obligations foncières ou lettres de gage émises par le Crédit Foncier de France, Thèse pour le doctorat, Université de Paris, Faculté de Droit (Paris: Librairie de la Société du Recueil J.-B. Sirey et du Journal du Palais, 1907), 26
} 
each equal in value to the other [...] Their intrinsic, particular character has to be modified, which will allow them to circulate, not only through endorsement like bills of exchange, but even as bearer certificates. ${ }^{96}$

The great work of mobilizing land values depended not, as Mengin and proponents of the cédule had had it half a century previously, on the particularization of land, but on its homogenization.

\section{Conclusion}

The creation of the Crédit Foncier and the legislative reforms that accompanied its expansion effected a substantial reworking of the nation's system of real property registration and circulation. Its centralized system of mortgage lending and financialization was a milestone in the capitalist constitution of real property relations, reliant on the decades of debate chronicled above. A law of 23 March 1855, put in place largely to facilitate the bank's activities, answered some of reformers' complaints regarding the invisibility of particular kinds of property transactions. Sales, for instance, would henceforth have to be recorded if they were to be binding on third parties. Yet the hidden mortgages of wives and minors remained exempt. Official record-keeping continued to operate merely as the record of a right rather than the legal force constituting that right, and no changes were introduced regarding the negotiability of mortgage titles. For opponents of more extensive mobilization, this was a relief. When Troplong surveyed the plethora of projects for the mobilization of land that had been debated in the revolutionary moment, he eagerly dismissed the period's wild ambitions, which despite "having exploded in the assembly, in books, and in newspapers" amounted to nothing but "vain and chimerical utopias," now happily buried under "ridicule and disdain from which they can never recover while common sense governs in France."97

\footnotetext{
${ }^{96}$ Wolowski, De l'organisation du crédit foncier, 78

97 Troplong, Privilèges et hypothèques, Commentaire de la loi du 23 mars 1855, 11.
} 
Yet adherents of more radical reform of the real property regime did not go away, raising mobilization schemes persistently. They featured as possible solutions to budget shortfalls, as for example when in 1883 the Chamber of Deputies debated proposals for the creation of 'billets hypothécaires' or mortgage notes that would be issued to property owners on up to a quarter the value of their property, guaranteed by the state and, for the service, return to the country's coffers $2.5 \%$ interest. $^{98}$ They were returned - if not pursued - by experts convened in the country's cadastral commission, which sat for fifteen years from 1891, charged with revising the legal, fiscal, and political standing of the country's cadastre in light of a collapse in rural land values and a perceived crisis of morcellement, or subdivision, of agricultural land. ${ }^{99}$ This commission embraced proposals from jurist and student of land questions, Jules Challamel, for the creation of bons hypothécaires (mortgage coupons) modeled directly on Mengin's cédule, with some additional inspiration from Prussian property law, mobilization practices from other German territories, and reforms to the circulation of real property instituted in Algeria. ${ }^{100}$ As with other areas of national life, for mobilization France's expanding imperial jurisdictions provided fecund spaces of mental and practical experimentation. ${ }^{101}$ In North Africa,

\footnotetext{
${ }^{98}$ Projet de loi de M. Fleury, député de l'Orne, Journal Officiel, 19 juin 1883; see Georges Rondel, La mobilisation du sol en France. Ses origines, son avenir, son application actuelle (Paris: Librairie nouvelle de droit et de jurisprudence, 1888), 220-221.

${ }_{99}$ Pierre Caziot, La Valeur de la terre en France (Paris: J.-B. Baillière et Fils, 1914), 8; Edmond Michel, Etudes statistiques économiques, sociales, financières et agricoles. Tome 3, La Propriété (Paris: Berger-Levrault et Cie, 1908), 101-3; Foville, Etudes économiques et statistiques sur la propriété foncière.

100 Jules Challamel, Ministère des Finances. Commission extraparlementaire du cadastre. Sous-commission juridique. Rapport général sur les privilèges et hypothèques (Paris: Imprimerie Nationale, 1901). See also Jules Challamel, De la cession des créances hypothécaires, étude sur les cédules hypothécaires (Handfesten, bons fonciers) (Paris: Challamel aîné, 1878).

${ }^{101}$ For colonies as landscapes of social and environmental transformation, see Osama Abi-Mershed, Apostles of Modernity: Saint-Simonians and the Civilizing Mission in Algeria (Stanford: Stanford University Press, 2010), Diana Davis, Resurrecting the Granary of Rome: Environmental History and French Colonial Expansion in North Africa (Athens, OH: Ohio University Press, 2007); Gwendolyn Wright, "Tradition in the Service of Modernity: Architecture and Urbanism in French Colonial Policy, 1900-1930," in Tensions of Empire: Colonial Cultures in a Bourgeois World, eds. Frederick Cooper and Ann Laura Stoler (Berkeley: University of California Press, 1997), pp.322-45; Herman Lebovics, True France: The Wars over Cultural Identity, 1900-1945 (Ithaca: Cornell University Press, 1992).
} 
Southeast Asia, and the Pacific, France confronted territories and polities whose patterns of land ownership were interpreted as ideological and economic obstacles to imperial ambitions. ${ }^{102}$ In Algeria, where colonizers sought to defend the principle of (European) property even as (indigenous) property rights were being violated, the problem of making property where none was deemed to exist and of regulating its circulation occupied state authorities from the beginning of French occupancy. ${ }^{103}$ As the century advanced, French financial interests also became increasingly attracted to the profits to be gained from mortgage lending abroad, seeking to align local conditions with those in Europe. The Crédit Foncier expanded to Algeria in 1880, Tunisia in 1909, and Morocco in 1913, while France was directly involved in the 1876 reform of Egypt's judicial system which clarified the treatment of real property and mortgages, smoothing the way for the introduction of the Crédit Foncier Egyptien (under French direction) in $1880 .{ }^{104}$ These developments were part of an international intensification of imperial projects in the second half of the nineteenth century, a crucial component of which was the refinement and application of systems regularizing the creation, transmission, and marketization of property titles. ${ }^{105}$ The most prominent became known as the Torrens System, the common name for the

\footnotetext{
${ }^{102}$ Didier Guignard, "Les inventeurs de la tradition 'melk' et 'arch' en Algérie," in Les Acteurs des transformations foncières autour de la Méditerranée au XIXe siècle eds. Vanessa Guéno et Didier Guignard (Paris: Editions Karthala, 2013), pp. 49-93. Early work by M.-G. Worms was influential on French (mis)understanding of Muslim law and common property: Recherches sur la constitution de la propriété territorial dans les pays musulmans, et subsidiarement en Algérie (Paris: Franck, 1846, 2e ed.).

${ }^{103}$ François Dumasy, "Propriété et société coloniale: La Commission de colonisation et la Mitidja en 1842-1843," in Propriété et société en Algérie contemporaine, Quelles approches?, ed. Didier Guignard (Aix-en-Province: Institut de recherches et d'études sur le monde arabe et musulman, 2017), pp.1-17.

${ }^{104}$ Hubert Bonin, Un outre-mer bancaire méditerranéen: histoire du Crédit Foncier d'Algérie et de Tunisie (18801997) (Paris: Publications de la Société française d'histoire d'outre-mer, 2004); idem., "La Compagnie algérienne levier de la colonisation et prospère grâce à elle (1865-1939)," Revue française d'histoire d'outremer 87, no.328329 (2000): 209-230; Sudel Fuma, Un Exemple d'impérialisme économique dans une colonie française au XIXe siècle: l'Île de la Réunion et la société du Crédit Foncier Colonial (Paris: L'Harmattan, 2001); Samir Saul, La France et l'Égypte de 1882 à 1814: Intérêts économiques et implications politiques (Paris: Ministère de l'Économie des Finances et de l'Industrie, 1997).

${ }^{105}$ Brenna Bhandar, Colonial Lives of Property: Law, Land, and Racial Regimes of Ownership (Durham: Duke University Press, 2018); Andrew Sartori, Liberalism in Empire: An Alternative History (Berkeley: University of California Press, 2014); Jennifer Pitts, A Turn to Empire: The Rise of Imperial Liberalism in Britain and France (Princeton: Princeton University Press, 2005).
} 
registration regime eventually consolidated in Australia's Real Property Act (1886) and applied to varying degrees throughout Britain's and France's empires. ${ }^{106}$ The possible utility of the Torrens System for improving metropolitan as well as colonial property relations proved a rich field of discussion and agitation among French mobilizers. ${ }^{107}$ Numerous politicians and technical experts, including those sitting on the longstanding cadastral commission convened in 1891 , recommended the importation into France of a livre foncier: a register of real property endowed with legal authority to effect, not merely record, ownership. ${ }^{108}$ Authorities tended, however, to agree with a speaker at an 1889 Congress on Land Transfers who concluded that in the realm of property, measures that were "necessary for new countries" would thoroughly disturb the venerable traditions of "a perfectly civilized country." 109

It is no surprise that significant interest and innovation in mobilization came from reforms designed for and implemented in France's empire. Mobilization had long been associated with the blind extraction of imperialism, wherein real property figured as nothing but a financial asset, shorn of moral and political attributes. In the context of the 1841 national consultation, for example, the Ministry of Justice affirmed that mobilizing land would turn the

\footnotetext{
${ }^{106}$ On the international genesis of the system, see Greg Taylor, "Is the Torrens System German?" Journal of Legal History 29 no.2 (August 2008): 253-285. For French imperial applications, see Alfred Dain, Le Système Torrens. De son application en Tunisie et en Algérie (Alger: Adolphe Jourdan, 1885); Paul Lescure, Du double régime foncier de la Tunisie (Tunis: Borrel, 1900). Studies for Tunisia's new property regime of 1885 can be found in AN 20020495/18: Tunisie, régime foncière.

${ }^{107}$ Much of the French discussion of the Torrens System drew inspiration from the studies of economist and politician Yves Guyot; see his series of articles in Le Globe (28 July, 11 August, and 1 September 1882; 28 September and 5 October 1883; 25 April 1884) as well as debate at the Society for Political Economy ("De l'application en France de l'Acte Torrens sur la propriété foncière," Journal des économistes (August 1883): 288295.) See also Léon Estivant, Etude sur la mobilisation de la propriété foncière dans l'acte Torrens (Paris: Arthur Rousseau, 1899); Maurice Tourolle, La Cédule hypothécaire: Etude historique et critique (Paris: A. Pedone, 1912). ${ }^{108}$ On the livre foncier, see Alexia Yates, Selling Paris: Property and Commercial Culture in the Fin-de-siècle Capital (Cambridge: Harvard University Press, 2015), 128-130. On the cadastral commission, Sylvie Devigne, "La Commission extraparlementaire du cadastre de 1891 à 1905: le projet de transformation du cadastre français en cadastre juridique," in De l'estime au cadastre en Europe, pp.217-231.

${ }^{109}$ Ministère du commerce, de l'industrie, et des colonies, Congrès international pour l'étude de la transmission de la propriété foncière, (Paris: Imprimerie Nationale, 1889), 11. The speaker was Jules Lefebvre, head of the Chamber of Notaries of Lille.
} 
French farmer into "a simple colonist on his field, either idly cultivating it or working it to death at the expense of public wealth." ${ }^{110}$ It was in the colonies that the process of making real property into a reliable security in part by ensuring that it could be easily identified and repossessed by creditors was most transparent. This paradox of possession and dispossession was inherent to mobilization. Mengin dedicated large portions of his writings on the cédule to formulas for property seizure, and Charles Dupin's argument for reconsidering the regime of real property circulation in the Chamber of Deputies in 1836 lionized commerce, where "everything is quick - seizing goods, seizing individuals," regretting that similar dispositions did not exist for real property. ${ }^{111}$ Similarly, it is no coincidence that the national consultation of 1841 overlapped with comprehensive revisions to procedures on the seizure of real estate (Law of 2 June 1841), or that the committees of the National Assembly that so thoroughly reconsidered laws on the mobilization of property under the Second Republic likewise tackled property seizure formalities. ${ }^{112}$ The dynamics of abstraction and materialization with which participants in the mobilization debate were grappling did not simply amount to a diachronic process by which modern forms of credit (the commercial, the personal) seemed to gain precedence over traditional forms (the real) as 'civilization' advances - though this was certainly how many polemicists understood the situation. The fixing of real property more securely in juridical space and movable instruments; its fluid mobility via commerciable paper forms; the tension between security of title and insecurity of tenure (for unwary debtors) - these collisions of mobilier and immobilier were repeatedly re-instantiated, not resolved or surpassed. The enduring nature of

\footnotetext{
${ }^{110}$ Documents relatifs au régime hypothécaire, vol.1, xcv

${ }^{111}$ See Mengin, Nouveau plan d'hypothèque; Chambre des députés, séance du 16 avril 1836, in Archives parlementaires, 166-167.

${ }^{112}$ Eugène Garsonnet, Traité de la saisie immobilière et de la procédure d'ordre (Paris: Larose et Forcel, 1891); AN F70 62: Rapport fait au nom de la Commission de la réforme hypothécaire et du crédit foncier, sur l'expropriation forcée, la procédure de saisie immobilière, et la procédure relative aux autres ventes judiciaires, par M. de Vatimesnil, 25 novembre 1850.
} 
these debates in the nineteenth century is explained by the profound institutional and imaginative hold that real property exercised as a source of value and stability in understandings of the economy. Even Paul Leroy-Beaulieu, France's premiere liberal economist at the end of the nineteenth century, described "la richesse mobilière" or movable wealth as stemming fundamentally from real property: "The term movable wealth generates numerous observations; it conjures notions of circulating, disposable capital, such as money, renewable bills of exchange, merchandise, 'fungible goods.' But that's not it at all; the largest part of so-called movable wealth is nothing more than real wealth transformed into securities that can be relatively easily bought and sold."113

For this reason, the debate on mobilization continues, due to productive dynamics at the heart of capitalism and certain durable qualities in land itself and the standing of property relations within that system. Based on the foregoing discussion, it is difficult to identify whether an endorsement of the benefits of centralized property registration for smallholders that proclaims that "without these representations, their assets are dead capital" was written in the 1780s, 1880s, or the 2000s. ${ }^{114}$ Rather than congealing into a teleological narrative of the financialization of everything, the debates presented in this article instead reveal the persistent difficulties and repeated failures of shifting groups of mobilizers, and the contingent political contexts that shape conditions of both action and discourse. Looking closely at the instantiation of land's abstraction in a particular time and place reveals numerous insights. Least surprising amongst them, perhaps, but necessary to underline, is the fact that markets are made; exchangeable goods and calculative economic agents are created and assembled by a range of

\footnotetext{
${ }^{113}$ Paul Leroy-Beaulieu, Essai sur la répartition des richesses et sur la tendance à une moindre inégalité des conditions (Paris: Guillaumin et Cie., 1897 [1881]), 230.

${ }^{114}$ Hernando de Soto, The Mystery of Capital: Why Capitalism Triumphs in the West and Fails Everywhere Else (New York: Basic Books, 2000), 6.
} 
technologies, from the cédule to the lettre de gage, technologies that are themselves shaped by the goods and agents upon which they act. Importantly, for the case of a market in land and its derivatives, the physical characteristics of land, reinforced by law, strong political commitment to private property, and land's standing as a powerfully national, territorial resource, play important roles in shaping that market. In nineteenth-century France, the state had not identified a clear interest in the circulation rather than the fixity of land. More precisely, it had yet to find efficient ways to distinguish between the classes and interests for whom fixity was to be fostered and those for whom mobility was desired. The importance of the nation-state and, by extension, of the national case study, shows through implacably in the process of territorial abstraction. The many ways that real property remains physically, socially, and nationally embedded makes the processes of abstraction to which it is subject of crucial importance for the study of both modern economies and modern states. 